\title{
Prezentacje
}

\section{Filozoficzna rola choroby}

Havi Carel
Żródło: Havi Carel, The

Philosophical Role of Illness,

w: Phenomenology of

Illness, Oxford University

Press, Oxford 2016.

TEKSTY DRUGIE 2021, NR 1, S. 215-244

DOI: 10.18318/td.2021.1.14 | ORCID: 0000-0002-1260-2362

Bo co to znaczy: ostatkami już gonisz? Znaczy to zbliżać się do tej chwili, kiedy dusza weźmie rozłąkę z ciałem. ${ }^{1}$

$\mathbf{0}$ d Wprowadzenia zatoczyliśmy koło². Zaczynaliśmy od pytania, w jaki sposób fenomenologia może być wykorzystana do wyjaśniania choroby. We wcześniejszych rozdziałach książki sprawdzałam, jak takie wyjaśnienie może nastąpić, tzn. jak można pouczająco spożytkować filozofię do rozumienia doświadczenia choroby i jej głębokich struktur.

Jako przydatna metoda opisu przeżywanego doświadczenia, w szczególności właśnie przeżywanego

1 Epiktet Diatryby; Encheiridion z dodaniem Fragmentów oraz Gnomologium epiktetowego, przeł. L. Joachimowicz, PWN, Warszawa 1961, s. 246 .

2 Niniejszy tekst opublikowano w pierwszej wersji jako artykuł: The philodophical role of illness, "Metaphilofophy” 2014, vol. 45, no. 1, s. 20-40. Po dokonaniu niezbędnych zmian stał się rozdziałem 9 książki pt. Phenomenology of illness, Oxford University Press, Oxford 2016.

\section{Havi Carel -}

profesor filozofii na Uniwersytecie Bristolskim. Prowadzi badania dotyczące opieki medycznej, doświadczenia choroby i komunikacji między pacjentami a lekarzami. Autorka monografii Phenomenology of Illness (2016), Illness (2008, 2013), nominowanej do Wellcome Trust Book Prize oraz Life and Death in Freud and Heidegger (2006). Współredaktorka książek Health, Illness and Disease (2012, wraz z Rachel Cooper) oraz What Philosophy Is (2004, wraz z Davidem Gamezem). 
doświadczenia choroby, została wybrana fenomenologia. Zbadałam, w jaki sposób choroba zmusza osobę chorą do modyfikowania jej związków ze środowiskiem i innymi ludźmi oraz podejścia do życia, śmierci i wartości. Następnie zaprezentowałam pojęcie niepewności cielesnej ${ }^{3}$ i przyjrzałam się konkretnym przykładom fenomenologii choroby, mianowicie doświadczeniu patologicznych duszności. Zadałam pytanie o negatywny wpływ choroby na poczucie szczęścia; dowiedzieliśmy się, że zasadniczo nie zmniejsza ona dobrego samopoczucia. Zwróciłam się więc ku Heideggerowskiemu pojęciu śmierci i strukturze ludzkiej egzystencji jako skończonej czasowości. Wreszcie zasugerowałam, że analizy interakcji wewnątrz systemu opieki zdrowotnej z pomocą pojęcia epistemicznej niesprawiedliwości mogą ujawniać wiarygodne deficyty, na które osoby chore są podatne.

W ostatnim rozdziale chciałabym się zwrócić w innym kierunku tego dwustronnego związku między chorobą a filozofią. Filozofia bowiem nie tylko wyjaśnia chorobę, choroba - jak to tutaj sugeruję - może również wyjaśniać filozofię. Ten rozdział jest poświęcony filozoficznej roli choroby; stwierdzam w nim, że rola ta jest ważna, ale pomijana, oraz przytaczam przykłady jej wkładu w myśl filozoficzną 4 .

Warto zaznaczyć na wstępie, że wiele obszarów ludzkiej egzystencji, które są postrzegane jako dla niej centralne - jak rodzina, miłość, zdrowie i choroba oraz dobre samopoczucie - znajduje słabe odzwierciedlenie w historii filozofii, a przede wszystkim we współczesnej filozofii akademickiej. Sprawy egzystencjalnie istotne dla większości ludzi, jak chociażby starzenie się, rodzicielstwo czy ochrona środowiska, nie przyciągały zbyt dużej uwagi filozofów. Nawet jeśli znalazły się w centrum zainteresowania, dyskutowane były wąsko, na przykład w kontekście rozpatrywania etyki rodzicielstwa, zamiast w kontekście systematycznej eksploracji miejsca i znaczenia relacji w ludzkim życiu.

3 Havi Carel używa określenia bodily doubt, które odnosi się do utraty "wiary we własne ciało" i przejrzystości doświadczenia cielesności, jest stanem załamania się "cielesnej pewności", czymś, co charakteryzuje zwątpienie w sprawność, niezmienność ciała - przyp. tłum.

4 W tym rozdziale nadal używam terminu "choroba" (illness) do określenia choroby poważnej, przewlekłej lub zagrażającej życiu, a nie chorób powszechnych i przemijających, takich jak grypa. Jednak również mniej poważne stany mogą być istotne z filozoficznego punktu widzenia, ponieważ ujawniają poboczne przeszkody w przepływie doświadczeń. Jean-Paul Sartre podaje tutaj przykład bólu głowy jako przeszkadzającego w czytaniu, co omawiałam w rozdziale 2, pt. "Fenomenologiczne cechy ciała" (zob. J.-P. Sartre Being and nothingness: an essay on phenomenological ontology, trans. by H.E. Barnes, Routledge, London-New York 2003 [1943]; wyd. polskie: Byt inicość. Zarys ontologii fenomenologicznej, przeł. J. Kiełbasa i in., Zielona Sowa, Kraków 2007). 
Choroba również należy do marginalizowanych tematów. Filozofia medycyny (lub filozofia zdrowia i choroby) nadal nie jest uważana za problematykę głównego nurtu, lecz za fakultatywny obszar specjalizacji. Ktoś mógłby powiedzieć, że ten krytycyzm wynika z przekonania, iż filozofia powinna zajmować się całym ludzkim życiem, takie oczekiwanie jest więc nieuzasadnione. Nie jest moim celem roszczenie tego typu, wyrażam jedynie zdziwienie brakiem filozoficznej dyskusji o tak podstawowych obszarach życia. Odpowiedź, że być może nie ma niczego interesującego dla filozofii w tych obszarach, rodzi kolejne pytanie, z całą pewnością bowiem taka filozoficzna eksploracja ma za zadanie odnalezienie tego, co można filozoficznego powiedzieć o wspomnianych obszarach i jak mogą one łączyć się z debatami etycznymi, filozoficzno-politycznymi czy metafizycznymi. Przypisywanie ich jedynie do kategorii określonych jako „prywatne”, ,subiektywne” czy „anegdotyczne” jest głęboko niesatysfakcjonujące.

Jasna analogia rysuje się tutaj w odniesieniu do filozofii feministycznej, która stopniowo mierzyła się z takimi tematami, jak przemoc domowa, molestowanie seksualne, rodzenie dzieci oraz seksualność - które to tematy początkowo w minimalnym stopniu skupiały uwagę filozofów. Wierzę, że choroba, starzenie się, wrażliwośćs i dzieciństwo mają przed sobą podobny $\operatorname{los}^{6}$. Poza tym filozoficzne zaniedbanie choroby znajduje się w kontrze do nieporównywalnie większego zainteresowania chorobą w innych dyscyplinach, jak chociażby w socjologii, antropologii, prawie, historii czy bioetyce, by wymienić kilka, zauważalnego także w niedawnym wysypie prac z zakresu humanistyki medycznej. Jest to również zaskakujące, jeśli weźmiemy pod uwagę duże społeczne zainteresowanie chorobą i opieką zdrowotną (jako przykłady można podać olbrzymią popularność patografii, forów internetowych dotyczących zdrowia i popularnych w historii medycyny form pisarskich np. „biografii” choroby)?

5 Chodzi o wrażliwość w sensie vulnerability, czyli poczucia podatności i bezbronności - przyp. tłum.

6 Aktualna literatura dotycząca starzenia się zob. „Philosophical Papers” 2012 vol. 41, no. 3, Special Issue: Aging and the elderly, ed. by J. Cottingham. Informacje na temat dzieciństwa w historii filozofii zob. A. Krupp Reason's children: childhood in early modern philosophy, Bucknell University Press, Lewisburg, PA 2009.

7 Zobacz na przykład serię Oxford University Press „Biographies of Disease”, http://ukcatalogue. oup.com/category/academic/series/medicine/bod.do (21.10.2014 [link nieaktualny, zob. np. http://solo.bodleian.ox.ac.uk/primo-explore/search?vid=SOLO\&search_scope=LSCOP_ALL\&query=any, contains,Biographies\%200f\%20Disease (20.01.21) - przyp. red.]). 
W przeciwieństwie do współczesnej filozofii choroba była tematem dla dawniejszych filozofów, szczególnie w relacji do związanych z nią wartości moralnych, egzystencjalnych i duchowych. Na przykład dla stoickich filozofów I wieku naszej ery, jak Epiktet ${ }^{8}$ i Seneka ${ }^{9}$, II wieku - Marka Aureliusza ${ }^{10}$; V wieku - Boecjusza" ${ }^{11}$, czy w czasach nowożytnych Kartezjusza ${ }^{12}$. Pisali oni o chorobie i o tym, jak kształtowała ona dobór sposobów i tematów filozofowania. Ci myśliciele zwracają też uwagę na związek między zdrowiem a cnotą oraz wpływem zdrowia na dobre życie, o czym piszę w dalszej części tego tekstu ${ }^{13}$. W Rozprawie o metodzie Kartezjusza z 1637 roku znalazł się następujący komentarz:

nawet umysł bowiem jest $\mathrm{w}$ tak wielkiej zależności od temperamentu i od układu narządów ciała, że jeśli tylko jest możliwe znalezienie jakiegokolwiek środka, który by uczynił ludzi na ogół mądrzejszymi i zręczniejszymi, niż byli dotychczas, mniemam, iż należy go szukać w medycynie. ${ }^{14}$

Kartezjusz postrzegał zdrowie jako naczelne dobro i podstawę wszystkich innych dóbr tego życia ${ }^{15}$. Prawdopodobnie najbardziej znane jest podejście

8 Epictetus A selection from the discourses of Epictetus with the Encheiridion, transl. by G. Long, 2003, http://www.gutenberg.org/files/10661/10661-h/10661-h.htm (20.08.2013); wyd. polskie: Epiktet Diatryby; Encheiridion z dodaniem Fragmentów oraz Gnomologium epiktetowego.

9 Seneca On the shortness of life, transl. by C.D.N. Costa, Penguin Book, London 2004; wyd. polskie: Seneka Pisma filozoficzne, cz. 1, przeł. L. Joachimowicz, Instytut Wydawniczy Pax, Warszawa 1965.

Marcus Aurelius Meditations, transl. by M. Hammond, Penguin Books, New York-London 1995; wyd. polskie: Marek Aureliusz Rozmyślania, przeł. K. Łapiński, Czarna Owca, Warszawa 2014.

Boethius The consolation of philosophy, transl. by H.R. James, 2004. http://www.gutenberg.org/ files/14328/14328-h/14328-h.htm (20.08.2013); wyd. polskie: Boethius O pocieszeniu jakie daje filozofia, przeł. W. Olszewski, PWN, Warszawa 1962.

Descartes Discourse on method, w: Descartes: selected philosophical writings, transl. by J. Cottingham, R. Stoothoff, D. Murdoch, Cambridge University Press, Cambridge 1988 [1637], s. 2056; wyd. polskie: Kartezjusz Rozprawa o metodzie, przeł. W. Wojciechowska, PWN, Warszawa 1988.

Mowa o utworach wymienionych powyżej: Boethius O pocieszeniu jakie daje filozofia (Consolation of Philosophy) księga IV; Seneka O krótkościżycia (On the Shortness of Life), Epiktet Diatryby (Discourses) oraz Marek Aureliusz Rozmyślania (Meditations). 
Michela de Montaigne'a, który za Sokratesem twierdził, że głównym celem filozofii jest przygotowanie nas na chorobę i ostatecznie śmierćn ${ }^{16}$.

Filozoficzna refleksja nad chorobą w tradycji zachodniej uformowana została przez stoicyzm, epikureizm, a później filozofię chrześcijańską; każda z nich przykłada dużą wagę do refleksyjnego radzenia sobie z chorobą, widzianego jako kluczowa funkcja świata. Dlaczego to refleksyjne podejście do choroby jest ważne, zależy od danej tradycji. Stoicy zdają się dowodzić, że wszystko, co istnieje - włącznie z pozornie złymi rzeczami, jak choroba ma istotne komponenty racjonalnego porządku kosmosu, a co za tym idzie, właściwą filozoficzną odpowiedzią jest rozpoznanie i refleksyjna akceptacja choroby. Epiktet mówi:

Nie wolno nam w czasie, kiedy nas spala gorączka, odrzucać ze wzgardą wszystkich nauk filozoficznych ani ich hurtem w niepamięć puszczać i mówić sobie: „Jeżeli kiedykolwiek zacznę ja znowu filozofować, to niechaj się stanie, co tylko się losom podoba. Teraz trzeba mi dokądś się udać i tam ciała doglądać". - Oczywiście, jeżeli gorączka nie pójdzie tam z tobą. A co to właściwie znaczy, że ktoś uczył się filozofii? Czy nie znaczy to tyle, że się uzbrajał i hartował przeciwko wszelkim przypadkom losu? ${ }^{17}$

Natomiast dla późniejszych myślicieli chrześcijańskich, jak Boecjusz, choroba jest śladem naszego zepsucia, niedoskonałego stanu, a więc czegoś dalekiego od oryginalnego boskiego pierwowzoru. Boecjusz charakteryzuje grzeszność duszy jako pokrewną cielesnej chorobie; jeśli jednak grzesznik zasługuje na potępienie, to chorego należy traktować ze współczuciem ${ }^{18}$. Właściwą filozoficzną odpowiedzią jest więc wykorzystanie choroby w podwójnie moralizatorski sposób: po pierwsze, jako przypomnienia o naszym wątłym i niestabilnym statusie moralnym, a po drugie, jako źródła odnowy moralnej i duchowej ${ }^{19}$.

16 M. de Montaigne To philosophise is to learn how to die, w: tegoż, The essays: a selection, transl. by M.A. Screech, Penguin, London 1993 [1580], s. 17-36; wydanie polskie: Próby, przeł. T. Boy-Żeleński, Zielona Sowa, Warszawa 2004.

17 Epiktet Diatryby; Encheiridion z dodaniem Fragmentów oraz Gnomologium epiktetowego, s. 224-225 .

Boecjusz O pocieszeniu jakie daje filozofia, s. 108.

19 I.). Kidd Can illness be edifying?, "Inquiry” 2012 vol. 55, no. 5, 2012, s. 496-520. 
Obecnie temat ten jest prawie całkowicie przemilczany przez filozofię, głównie ze względu na stopniową erozję jej fronetycznej roli ${ }^{20}$. Proponuję więc, by poświęcić więcej uwagi badaniu i opisowi filozoficznej roli choroby. W tym rozdziale wskazuję niektóre ze sposobów czynienia choroby filozoficznie istotną ${ }^{21}$. Sugeruję, że choroba ma duże znaczenie dla filozofii, ponieważ odkrywa aspekty cielesnego istnienia i doświadczania tak, by odsłonić ważne wymiary ludzkiego życia. Robi to, poszerzając spektrum doświadczeń cielesnych o sferę patologii, jednocześnie rzucając światło na normalne przeżycia, odkrywając ich zwyczajną, a tym samym pomijaną strukturę. Choroba poszerza zakres cielesnego i umysłowego doświadczenia (np. urojenia, demencja). Ponadto obecnie choroba jest integralną częścią życia biologicznego, musi więc być brana pod uwagę przy postrzeganiu ludzkiego życia jako całości.

Dyskusje o dobrym życiu, relacjach międzyludzkich czy etyce byłyby niekompletne, gdybyśmy nie brali pod uwagę pełnego spektrum ludzkiego życia i doświadczenia, obejmującego chorobę i zdrowie, dzieciństwo, dorosłość i starość, a także wzrastającej złożoności takich pojęć, jak autonomia czy wybór. Dodatkowo choroba jest okazją do refleksji ze względu na efekt dystansujący, który podkreśla brane za pewnik wartości i oczekiwania, burząc założenia leżące u ich podstaw (chociażby założenia o długowieczności, dobrym życiu i autonomii). Sugeruję więc, że te cechy gwarantują chorobie jej filozoficzną rolę.

Choroba jest jednak wyjątkową formą filozofowania. Podczas gdy stosowanie większości filozoficznych procedur, takich jak podawanie w wątpliwość czy kwestionowanie, ma charakter wolicjonalny i teoretyczny, choroba jest niespodziewana i zagrażająca. Choroba rzuca chorą osobę w objęcia lęku i poczucia niepewności. Jako taka może być postrzegana jako radykalna, gwałtowna motywacja filozoficzna, która potrafi dogłębnie zmienić naszą perspektywę. Sądzę, że ta radykalna jej natura powinna zostać wykorzystana zarówno w celu wyostrzenia, jak i poszerzenia dyskusji filozoficznej.

W filozofii medycyny toczy się wiele dyskusji na temat pojęcia choroby (z rozróżnieniem na illness i disease) oraz jej związku z pojęciem zdrowia. Niemniej ta analiza pojęciowa nie porusza roli egzystencjalnej ani filozoficznej, jaką może odgrywać choroba. Godnym uwagi wyjątkiem jest książka S.K. Toombs Meaning of illness: A phenomenological account of the different perspectives of physician and patient, Kluwer Academic Publishers, Dordrecht-Boston-London 1993; aczkolwiek zob. też M. Nussbaum The therapy of desire: theory and practice in hellenistic ethics, Princeton University Press, Princeton, NJ 1994. 
Poza tym choroba jest formą zaproszenia do refleksji filozoficznej, która prawdopodobnie ma bardziej uniwersalny i intymny charakter niż inne formy zaproszeń. Za przykład weźmy platońskie "poczucie zdumienia" jako podstawę filozoficznego impulsu, którego wielu ludzi nie doświadcza. Podobnie jest z metafizyczną i egzystencjalną ciekawością, uruchamiającą filozofowanie, ale nie przez wszystkich odczuwaną. Wszyscy jednakowoż umrzemy, a większość zachoruje i się zestarzeje. Dlatego już choćby te procesy stanowią zaproszenie do refleksji na temat faktów dotyczących własnego życia. Nie dla każdego mają znaczenie prawda, piękno czy natura rzeczywistości, ale praktycznie każdy interesuje się dobrym życiem, nawet jeśli oznacza to życie doświadczające - refleksyjnie i realnie - straty, bólu i cierpienia, które przynosi choroba.

Na zakończenie badam, w jaki sposób choroba może wpływać na praktykę filozoficzną. Twierdzę, że choroba może być integralna z podejściem filozoficznym na wiele sposobów: przez kształtowanie filozoficznych metod i problemów, modyfikowanie czyjegoś poczucia filozoficznej istotności i koncepcji filozofii oraz uwypuklanie konieczności podejmowania określonych kwestii filozoficznych. W podrozdziale 9.1 podkreślam centralne miejsce ciała w ludzkim doświadczeniu i rozważam, jak choroba zmienia cielesność, znaczenie i bycie w świecie. W podrozdziale 9.2 rozpatruję chorobę jako rodzaj zawieszenia lub epoché, wytwarzane w procesie uprzedmiotowienia i wyobcowania. W podrozdziale 9.3 rozpatruję chorobę jako motywację do filozofowania i podkreślam, jak choroba może zmieniać nasze sposoby i style filozofowania.

\subsection{Choroba zmienia cielesność, znaczenie i bycie w świecie}

Zacznijmy od podsumowania niektórych pomysłów omawianych we wcześniejszych rozdziałach książki. Trzy aspekty egzystencji są znacząco przekształcane przez chorobę: cielesność, znaczenie oraz bycie w świecie. Cielesność jest podstawową cechą ludzkiej egzystencji²2. Świadomość i zachowanie nie mogą być rozpatrywane bez uwzględnienia percepcji i aparatu

Zob.: M. Merleau-Ponty Phenomenology of perception, transl. by D. Landes, Routledge, New York 2012 [1945]; wyd. polskie: Fenomenologia percepcji, przeł. M. Kowalska, J. Migasiński, Fundacja Aletheia, Warszawa 2001; A. Clark Being there: putting brain, body, and world together again, MIT Press, Cambridge, MA 1997; tegoż Supersizing the mind: embodiment, action, and cognitive extension, Oxford University Press, Oxford 2008; M. Wheeler Reconstructing the cognitive world, MIT Press, Cambridge, MA 2005. 
ruchowego, ułatwiających nam radzenie sobie w świecie ${ }^{23}$. Ciało warunkuje możliwość percepcji oraz interakcji z obiektami w przestrzeni i jest naszym sposobem posiadania świata. Jak piszą Shaun Gallagher i Dan Zahavi, ciało jest postrzegane jako konstytutywny albo transcendentalny warunek, właśnie dlatego że jest zaangażowane w samą możliwość doświadczenia ${ }^{24}$. Każde ziemskie doświadczenie jest zapośredniczone i możliwe dzięki ciału². Lub jak ujmuje to Maurice Merleau-Ponty - ciało jest tym, co sprawia, że rzeczy zaczynają istnieć dzięki naszemu doświadczaniu ich za pomocą rąk i oczu ${ }^{26}$.

Wbrew czysto naturalistycznemu rozumieniu ciało nie jest wyłącznie rzeczą pośród innych rzeczy. Cielesność determinuje relacje przestrzenne i doświadczenia w czasie, a jednocześnie uczestniczy w tych relacjach jako forma drugorzędna. Ciało jest centrum, wokół którego i w relacji do którego przestrzeń się otwiera ${ }^{27}$. Zdaniem Edmunda Husserla, poruszanie się, doświadczenia dotykowe są podstawą nie tylko percepcji, ale każdego organicznego subiektywnego doświadczenia ${ }^{28}$.W tym sensie ciało jest podstawą ludzkiego doświadczenia. Taylor Carman pisze, że ciało odgrywa istotną rolę w doświadczeniu właśnie przez ugruntowanie, czynienie możliwym, przy jednoczesnym pozostawaniu peryferyjnym w horyzoncie naszej świadomości konceptualnej ${ }^{29}$. Możemy też użyć słynnego sformułowania Merleau-Ponty'ego, że ciało jest naszym głównym medium posiadania świata ${ }^{30}$.

Forma mojej cielesności służy jako część tła mojego doświadczenia ${ }^{31}$. Ta struktura definiuje na przykład system współrzędnych mojego pola widzenia i mojej orientacji. Różne pola zmysłowe są połączone ze sobą, by tworzyć

23 P. Calvo, T. Gomila Handbook of cognitive science: an embodied approach, Elsevier, Oxford 2008, S. 7 .

24 S. Gallagher, D. Zahavi The phenomenological mind, Routledge, New York 2008, s. 135.

D. Zahavi Husserl's phenomenology, Stanford University Press, Stanford, CA 2003, s. 99. M. Merleau-Ponty Phenomenology of perception, transl. by C. Smith, Routledge, New YorkLondon 1962, s. 146.

D. Zahavi Husserl's phenomenology, s. 99. shers, Dordrecht 1997 [1907]. T. Carman The body in Husserl and Merleau-Ponty, "Philosophical Topics” 1999 vol. 27, no. 2, s. 205-226, tu s. 208. 
wspólny strumień znaczącego doświadczenia, zjednoczony w ciele z ustalonym repertuarem nawyków, aktywności i stylem ${ }^{32}$. W odniesieniu do teorii Husserla składowe mojego ciała są niezbędne dla składowych pojawiających się przedmiotów, a także dla składowych przestrzeni i czasu³.

Mając na uwadze, jak centralne miejsce zajmuje ciało, zmiana w jego funkcjonowaniu pociąga za sobą przekształcenia w sposobie czyjegoś bycia w świecie. Będzie więc ona miała wpływ również na znaczenie doświadczenia. Na przykład doświadczanie tańca zmieni się radykalnie przy chorobie układu oddechowego, zarówno na poziomie odczuwania ciała - z formy przyjemnej przemieni się w wysiłek - jak i na poziomie znaczenia, kiedy

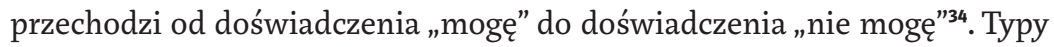
zmian spowodowane przez chorobę mogą bardzo się różnić - od zmian do doświadczeń zmysłowych oraz od znaczenia do kognitywnego i emocjonalnego doświadczenia.

Jeśli myślimy o objawach tak odmiennych, jak utrata sprawności ruchowej, utrata pamięci i nietrzymanie moczu, możemy zauważyć, że zmiany te są radykalne i usuwają chorego z domeny znanego, przewidywalnego i dobrze rozumianego doświadczenia. To przemieszczenie ze znanego destabilizuje strukturę doświadczenia i ujawnia nowe aspekty naszego bytu - jak nasza zdolność przystosowywania się, żałoba i zależność. Cielesne podstawy autonomicznej dorosłości są często usuwane, odsłaniając niepewny i tymczasowy charakter tych fundamentów. Choroba odgrywa więc ważną rolę egzystencjalną - może ujawnić skończoność, niepełnosprawność i wyobcowanie z ciała jako ekstremalne sposoby bycia.

Filozoficzne wyjaśnienia oparte na badaniu choroby rozwija Matthew Ratcliffe, który analizował doświadczanie czasu w depresji $i^{35}$. Ratcliffe twierdzi, że istnieją mocne dowody na to, że depresja wielorako wpływa na doświadczanie czasu. Proponuje on fenomenologiczną analizę tego doświadczenia, wykorzystując zastosowane przez Thomasa Fuchsa pojęcia retencji i protencji Husserla do doświadczania czasu w depresji. W tym przypadku czas zarówno zwalnia, jak i przyspiesza. Ta zmiana normalnego

32 Na temat stylu zob. D. Meacham What goes without saying: Husserl's notion of style , Research in Phenomenology" 2013 vol. 43, s. 3-26. Por. H. Carel Phenomenology as a resource for patients, "Journal of Medicine and Philosophy" 2012 vol. 37, no. 2, s. 96-113. M. Ratcliffe Varieties of temporal experience in depression, tamże, s. 114-138. 
doświadczania czasu może być wyjaśniona właśnie jako skutki depresji.Zdaniem Ratcliffe'a depresja usuwa znaczenie, zaciera chęć realizacji projektów i zatrzymuje przypisywanie wartości różnym projektom w świecie osób na nią cierpiących ${ }^{36}$. Twierdzi on, że załamanie $w$ takich przypadkach dotyczy nie tylko tre ś c i doświadczenia, lecz także samej jego s t r u k t u ry.

Ponieważ choroba może wpływać na wiele części i funkcji ciała, może nakreślić różne aspekty cielesności, służąc jako przypadek graniczny ${ }^{37}$. Utrata w chorobie może dotyczyć ogólnego funkcjonowania, a także elastyczności i zmienności. Przy zawężonym spektrum aktywności motoryka, ocena czasu trwania i pojęcia takie jak „trudne" $i$,dalekie" są modyfikowane. Ograniczenie jest nie tylko świadomym zrozumieniem, ale leży u podstaw tego rodzaju działania, które ciało wykonuje spontanicznie. Oto opis takiej przedrefleksyjnej zmiany:

Za każdym razem, gdy próbowałem - i nie udawało mi się - zrobić coś, co było zbyt forsowne, moje ciało ze stoickim spokojem rejestrowało awarię, a następnie unikało tej aktywności. Zmiana była subtelna, ponieważ zdarzyło się to podstępem [...]. Przestałem odczuwać wszystkie rzeczy, których nie mogłem zrobić. Zostały one po cichu usunięte z mojego repertuaru cielesnego w sposób tak subtelny, że prawie tego nie zauważyłem. ${ }^{38}$

Choroba może prowadzić do rozpadu znaczenia lub tego, co Heidegger nazywa lękiem ${ }^{39}$.W stanach lękowych gubi się ogólne poczucie celowej aktywności, przez co osoba doświadczająca lęku nie jest w stanie działać. Działanie ma uzasadnienie: zakładam koszulę przez głowę, aby się ubrać. Ubieram się, żeby iść do pracy. Idę do pracy, żeby zarabiać na życie, i tak dalej. Ostatecznie ten zagnieżdżony zestaw działań ukierunkowanych na cel dobiega końca, a ludzka egzystencja jest nieuzasadniona. Uświadomienie sobie bezpodstawności ludzkiej egzystencji prowadzi do czegoś, co Heidegger nazywa lękiem (Angst).

36 Tamże.

37 Śmierć nie byłaby ostateczną granicą, ale przekroczeniem granicy. Zob. H. Carel Illness, phenomenology, and philosophical method, "Theoretical Medicine and Bioethics" 2013 vol. 34, no. 4, s. 345-357.

H. Carel Illness: the cry of the flesh, Routledge, London 2013, S. 40-41.

39 M. Heidegger Being and time, transl. by J. Macquairre, E. Robinson, Basil Blackwell, Oxford 1962 [1927]; wyd. polskie: Bycie i czas, przeł. B. Baran, PWN, Warszawa 2008. 
W lęku celowość znika, a znaczenie bytów zostaje zatracone. Zmieniają się z bytu podręcznego (Zuhanden), z którego korzystamy (koszulka, buty, lampka do czytania), do bytu dostępnego (Vorhanden), który konfrontuje nas $\mathrm{z}$ ich brakiem przydatności, a zatem z brakiem znaczenia. W lęku traci się zrozumiałość, ponieważ utracona została praktyczna spójność bytów z poczuciem celowości.

Choroba może również prowadzić do innego rodzaju utraty znaczenia, związanej z utratą zdolności postrzegania rzeczy jako użytecznych narzędzi, oraz doświadczania przypadkowości i nieodwracalności znaczenia. W chorobie somatycznej gotowy do użycia byt, taki jak schody, może zmienić się z praktycznego narzędzia w byt obecny, a nawet widoczną przeszkodę. S. Kay Toombs, filozofka cierpiąca na stwardnienie rozsiane, pisze: „Regał przed moją sypialnią był kiedyś postrzegany przez moje ciało jako «miejsce na książki»; następnie jako «to, co należy chwycić jako wsparcie w drodze do łazienki», a teraz jest odbierany jako «przeszkoda w poruszaniu się na wózku»"40.

Choroba somatyczna może powodować nagłe i często niepokojące poczucie przypadkowości znaczeń i zastosowań, które przypisujemy rzeczom: „Regał zawiera książki. Oczywiście, że tak! Co jeszcze może robić? Może utrudniać, przeszkadzać, niestety przypominać...". Istnieje również poczucie nieodwracalności niektórych znaczeń: „regał zawsze będzie przeszkodą i przestanie nią być, dopiero gdy ja przestanę widzieć go jako przeszkodę". Poczucie zamieszkiwania przestrzeni możliwości może zostać zastąpione poczuciem ograniczenia i statyczności. Zmiany spowodowane przez chorobę nie są lokalizowane na konkretnym obiekcie, ale modyfikują całą interakcję z obiektami i otoczeniem, tj. ich obecność w świecie. Dla użytkownika wózka nie tylko ten sklep czy tamte drzwi są niedostępne, ale środowisko jako całość staje się mniej zachęcające, a nawet wrogie. Choroba może ujawniać nie tylko granice ludzkiej egzystencji, lecz także uprzedzenia środowiska.

Choroba może więc być filozoficznie istotna pod dwoma względami. W niektórych przypadkach jest to poważne i nagłe zakłócenie naszego życia. W tej sytuacji choroba jest czymś obcym, groźnym i destrukcyjnym, czego chcemy się pozbyć. Grypa lub infekcja żołądka są przykładami tego rodzaju dolegliwości. Są one filozoficznie użyteczne ze względu na ostre zakłócenia w życiu codziennym; uwidaczniają w oczywisty sposób, jak konstruujemy nasze codzienne życie. Przyjmujemy za pewnik, że możemy planować dzień,

40 S.K. Toombs The lived experience of disability, "Human Studies” 1995 vol. 18, s. 16. 
robić różne rzeczy i przenosić się z jednego miejsca do drugiego. Te milczące założenia są zawieszane na wypadek nagłej choroby. Uczucia utraty, bezużyteczności i złego samopoczucia ujawniają ukryte poczucie uczestnictwa, celowości i potencji, które zostały zaburzone ${ }^{41}$.

Choroba może również pojawiać się bardziej subtelnie. Objawy mogą być słabe i prawie niezauważalne, dopóki nie osiągną określonego poziomu lub nie zostaną wykryte podczas rutynowych badań przesiewowych. W tym wypadku dolegliwości nie są gwałtownym zaburzeniem codzienności, ale nadal wpływają na codzienne zdolności chorego, a zatem mogą również prowadzić do refleksji filozoficznej - choć innego rodzaju. Shaun Gallagher opisuje ten rodzaj choroby jako taką, która „albo się do nas zakrada, albo stajemy się tak przyzwyczajeni (być może dlatego, że nie zniknie), iż określa ona nasz sposób życia - staje się nami lub my stajemy się nią"42. Podczas gdy w ostrej chorobie oczekiwanie, że "pójdzie sobie”, jest w dużej mierze częścią doświadczenia choroby, oczekiwanie to znika, gdy chorujemy przewlekle. Arthur Frank przeciwstawia swój atak serca, który interpretował jako „incydent”, nowotworowi:

Po incydencie takim jak zawał serca byłem w stanie odbić się od dna [...]. To jest właściwe określenie, ponieważ w większości przypadków nie zagłębiamy się w doświadczenie, lecz uderzamy o jego powierzchnię. Być może odbiłem się od zawału serca, ale z rakiem musiałem zatonąć na całej długości i odkryć życie po drugiej stronie. ${ }^{43}$

Drugi rodzaj choroby to nie zakłócenie, lecz „kompletna forma istnienia”, jak pisze Gallagher, podążając za Merleau-Pontym ${ }^{44}$. W takim przypadku

Doświadczenie starzenia się również może wywołać te odczucia, ale raczej stopniowo, w przeciwieństwie do nagłej choroby. Pogląd każdej jednostki może zależeć od koncepcji starzenia, jaką przyjmuje dana osoba. Gerontofob/ka uzna, że starzenie się przyćmiewa jego/jej możliwości i tym samym wywołuje niepokój, ale gerontofil/ka - jak Cyceron lub Montaigne - dostrzeże pozytywne strony tej sytuacji, interpretując utratę możliwości jako naukę, gdyż Natura daje jednostkom szansę na wycofanie się z żywiołowej pogoni na rzecz poświęcenia się studiowaniu świata, refleksji, uprawianiu ogrodu. Dziękuję za tę uwagę lanowi Jamesowi Kiddowi.

42 S. Gallagher "Illness as a complete form of existence", niepublikowana prezentacja przedstawiona podczas corocznej konferencji the Association for Medical Humanities, University of Durham 2009.

A. Frank At the will of the body, Mariner Books, Boston 1991, s. 28.

44

S. Gallagher "Illness as a complete form of existence", por. M. Merleau-Ponty Phenomenology of perception. 
zaburzenie przebiega głębiej i przez dłuższy czas, dlatego należy sobie z nim radzić w inny sposób niż z chorobą przejściową, taką jak zatrucie pokarmowe. Kiedy choroba staje się kompletną formą życia, koncepcje (takie jak „wartościowe” lub „trudne”) są modyfikowane, zmieniają się oczekiwania chorego dotyczące życia, a rozumienie czasu i wartości musi zostać ponownie dostosowane do uzyskanych prognoz. Przewlekła lub postępująca choroba to kompleksowa zmiana znaczenia, wartości i sposobów bycia, która kończy się chorobą w postaci kompletnej formy egzystencji. Proces ten jest swego rodzaju dystansowaniem się od poprzedniej formy egzystencji i jako taki poddaje chorobę analizie filozoficznej.

\subsection{Choroba jako epoché: uprzedmiotowienie i niesamowitość}

Ponieważ choroba usuwa z góry przyjętą naturę mobilności i zdolności organizmu, sprawia, że to, co normalnie naturalne i nierefleksyjne, staje się sztuczne i świadome ${ }^{45}$. W tym podrozdziale wyjaśniam, w jaki sposób przejście od bezgłośnego i bez wysiłku do jawnego i wymagającego cielesności napędza filozoficzną refleksję. W przejściu od zdrowia do choroby doświadczenie cielesne staje się zarówno wyraźne, jak i negatywne, charakteryzuje się uprzedmiotowieniem i niesamowitością. Te dwa pojęcia służą tutaj do określenia roli choroby jako sposobu filozofowania.

Chorobę można postrzegać jako kryzys sensu życia. Wynika on z załamania się historii życia chorego ${ }^{46}$, a także z zakłócenia rutyny, nawyków, oczekiwań i umiejętności. To zakłócenie wstrząsa codziennym życiem i zapewnia dystans do niego. Dystans ten został opisany przez Arthura Franka jako „niebezpieczna okazja”:

Krytyczna choroba oferuje doświadczenie przeniesienia się na próg życia, z którego można zobaczyć, gdzie mogłoby zakończyć się twoje życie. $\mathrm{Z}$ tego punktu widzenia jesteście zarówno zmuszeni, jak i wolno wam myśleć w nowy sposób o wartości swojego życia. Żywi, ale oderwani od codziennego życia, możecie wreszcie przestać zastanawiać się, dlaczego właśnie tak żyjecie $[\ldots] .^{47}$

S. Gallagher How the body shapes the mind, Oxford University Press, Oxford 2005. 
Przypomina to starożytną grecką koncepcję filozofii, wprowadzoną przez Sokratesa i przyjętą przez stoików, a następnie uzupełnioną przez Montaigne'a, że filozofia polega na nauczeniu się, jak umierać ${ }^{48}$. W tym kontekście może oznaczać to coś więcej niż zaakceptowanie własnej śmiertelności. Zapewnia bowiem wysoce abstrakcyjne zapotrzebowanie na konkretną treść. Uczenie się, jak umierać, to umiejętność znoszenia choroby, zdobywania umiejętności radzenia sobie z bólem i niepełnosprawnością, akceptowanie malejących zdolności i panowania nad trudnymi emocjami, takimi jak żałoba, zazdrość i smutek. To wymagające zadanie może stanowić podstawę procesu potraumatycznego wzrostu i wyjaśnia, dlaczego doświadczanie różnych form cielesności i życia może prowadzić do rozwoju osobistego, moralnego i zwiększonej wrażliwości na cierpienie. Wzywa także do poprawnej reakcji, którą nazywam refleksyjnym radzeniem sobie. Takie radzenie sobie może pozwolić choremu dobrze znosić chorobę. Przykładowy zarys refleksyjnego radzenia sobie można znaleźć u Epikteta: „A co to znaczy dzielnie się sprawiać w czasie gorączki? Ano nie skarżyć się na boga ani na ludzi, nie załamywać się na duchu z powodu cierpienia, spokojnie i wielkodusznie gotować się na śmierć, a przy tym czynić, co czynić należy [...]"49.

Jak wspomniałam we wcześniejszych rozdziałach, choroba wzywa chorego do zbadania swojego życia, jego znaczenia, priorytetów i wartości. To osobiste poszukiwanie jest dobrze udokumentowane w socjologii medycyny, antropologii medycznej, badaniach jakościowych opieki zdrowotnej i psychologii raka ${ }^{50}$. Lecz chorobę można również wykorzystać jako wyraźnie filozoficzne narzędzie motywujące do refleksji, wychodząc poza idiosynkratyczne i osobiste do ogólnej i abstrakcyjnej eksploracji ucieleśnienia jako źródła znaczenia i warunku możliwości dla własnego ja.

W szczególności lęk, utrata sensu i niedostosowanie opisane w poprzedniej części powodują specyficzną formę tego, co Husserl nazwał epoché, zawieszeniem naszej „naturalnej postawy”. Epoché kieruje nas, abyśmy oderwali się od codziennych nawyków i rutyny, aby się nad nimi zastanowić. Sugeruję, że dzieje się tak w przypadku choroby, choć w sposób surowy

48 M. de Montaigne To philosophise is to learn how to die.

Epiktet Diatryby Encheiridion z dodaniem Fragmentów oraz Gnomologium epiktetowego, s. 246. vol. 10, no. 1, s. 1-18; S. Thorne, B. Paterson Shifting images of chronic illness, "Journal of Nursing Scholarship" 1998 vol. 30, no. 2, s. 173-178; S. Thorne i in. Chronic illness experience: insights from a metastudy, "Qualitative Health Research" 2002 vol. 12, no. 4, s. 437-452. 
i niesformułowany ${ }^{51}$. Choroba jest szczególną formą m o ty wa cji filo z o f i c z nej (philosophical motivation), narzuconą chorej osobie i charakteryzującą się przemocą i negatywnością.

Epoché prosi nas o przeniesienie naszej uwagi z przedmiotów na akty percepcji, ale nie oznacza zaprzestania postrzegania; to nie jest sceptyczna procedura. Jest to zmiana sposobu bycia w świecie, która umożliwia refleksję filozoficzną, bez zarzucenia bycia częścią świata. Ćwiczenie epoché polega na usunięciu wspólnych znaczeń i znanych powiązań między osobą a przedmiotem. Następnie obiekt uwalnia się od niewysłowionych (milczących) i akceptowanych do tej pory sposobów postrzegania i rozumienia go, po czym pojawia się w nowy sposób. Tak doświadczenie choroby lub lęku jako szczególnego rodzaju epoché może rzucić nowe światło na oczywiste aspekty świata ${ }^{52}$.

Choroba zawiesza naturalną postawę - przyjęty obciążony znaczeniem, metafizycznie determinowany sposób doświadczania świata. Takie zawieszenie nie oznacza rezygnacji z naturalnej postawy, co jest niemożliwe, ale utrzymanie tej postawy przy jednoczesnym zawieszeniu leżących u jej podstaw przekonań. Jest to swoista neutralizacja wiary w istnienie świata lub przedmiotu, co Husserl nazwał epoché. Ta neutralizacja jest wykorzystywana przy przejściu od naturalnego do krytycznego ${ }^{53}$.

Nie wpływamy na epoché, aby „zaprzeczyć, wątpić, zaniedbać, porzucić lub wykluczyć rzeczywistość z naszych badań, ale po prostu zawiesić lub zneutralizować pewien dogmatyczny stosunek do rzeczywistości [...]" ${ }^{154}$. Redukcja (bracketing) naturalnej postawy jest odejściem od zwykle domniemanego przywiązania do rzeczywistości świata ${ }^{55}$. Redukcja zamienia świat w fenomen bycia, zamiast tego, co jest.

51 Dystans może wynikać również z innych wydarzeń życiowych, takich jak żałoba, rozwód i inne traumy.

52 Jest prawdopodobne, że inne wydarzenia - takie jak wspomniana żałoba, wypadek, przeprowadzka do nowego kraju albo strata wieloletniej relacji - sprzyjają takim samym fenomenologicznym procesom przez erozję tego, co uznawane było do tej pory za pewne i niezmienne, a tym samym zwracając uwagę na te aspekty doświadczenia. Dziękuję osobie, która anonimowo podzieliła się ze mną tym komentarzem.

53 J. Drummond Historical dictionary of Husserl's philosophy, Scarecrow Press, Lanham, MD 2007, s. $67-68$.

M. Ratcliffe Feelings of being: phenomenology, psychiatry and the sense of reality, Oxford University Press, Oxford 2008, s. 4. 
Jak wyjaśnia Husserl, nie jest to pozycja sceptyczna ani idealistyczna. Przeciwnie, to "hamowanie" lub „wycofywanie się z gry” naturalnego podejścia ujawnia „moje czyste życie [...], wszechświat zjawisk w sensie fenomenologicznym" ${ }^{\prime 56}$.To zawieszenie nie kwestionuje ani nie neguje rzeczywistości; raczej pozwala niedocenionym aspektom doświadczenia stać się przedmiotem dociekań, ponieważ uprawnia nas do przeniesienia uwagi z danego obiektu na sposób, w jaki jest on dany i jak się pojawia. Husserl w Ideach I pisze: „cały znany świat, widziany w naturalnej postawie [...], jest teraz dla nas nieważny; bez testowania i bez kwestionowania należy wziąć go w nawias" ${ }^{\prime 27}$. Ale, co ważne, epoché „pozostawia wszystko dokładnie takim, jakie jest" ${ }^{\text {"s8 }}$.

Zahavi charakteryzuje epoché jako filozoficzną „bramę”.59. Sugeruję, że ze względu na działanie zmniejszające oswojenie i dystans choroba jest wstępem do filozofii. To zaproszenie do zbadania podmiotowości w chorobie, a tym samym do rozszerzenia warunków, w jakich bada się podmiotowość. Może ujawnić nowe aspekty podmiotowości, które w przeciwnym razie pozostałyby niezauważone. Wróćmy do przypadku Schneidera omówionego we wcześniejszych rozdziałach ${ }^{60}$. Merleau-Ponty interpretuje niezdolność Schneidera do wykonywania abstrakcyjnych ruchów, inicjowania relacji seksualnych lub porzucania codziennej rutyny jako załamanie jego zamierzonego łuku. Wykorzystuje to studium przypadku, aby wyjaśnić, jak łuk intencjonalny (intencional arc) działa normalnie, co pozostaje zazwyczaj niezauważone. Podobnie Shaun Gallagher omawia przypadek Iana Watermana, który cierpiał z powodu deaferentacji od szyi w dół. Waterman był zmuszony używać wzroku, aby lokalizować kończyny i określać swoją postawę, z powodu utraty czucia i propriocepcji ${ }^{61}$. Gallagher wykorzystuje przypadek Watermana, aby przedstawić opis zwyczajowej propriocepcji. Załamanie normalnej ludzkiej egzystencji daje wyjątkową okazję do odkrycia aspektów życia, które nie są zauważane.

E. Husserl Cartesian meditations, Kluwer Academic Publishers, Dordrecht 1988 [1931], s. 20; wyd. polskie: Medytacje kartezjańskie. Wprowadzenie do fenomenologii, przeł. A. Wajs, Wydawnictwo IFiS PAN, Warszawa 2009.

E. Husserl Ideas pertaining to a pure phenomenology and to a phenomenological philosophy: first book, Martinus Nijhoff, The Hague 1982 [1913], s. 62; wyd. polskie: Idee czystej fenomenologii i fenomenologicznej filozofii, przeł. D. Gierulanka, PWN, t. 1 Warszawa 1967, t. 2 Warszawa 1974.

A.D. Smith Husserl and the Cartesian meditations, Routledge, London-New York 2003, s. 23.

D. Zahavi Husserl's phenomenology, s. 46. 
W chorobie epochéjest $\mathrm{n}$ a $\mathrm{r}$ z u c a $\mathrm{n}$ a chorym $\mathrm{z}$ powodu zmian i ograniczeń nałożonych przez chorobę. Chory może nie być zainteresowany filozofią i nie chcieć ulegać przemianom egzystencjalnym. Jednak choroba - nieproszony gość - wprasza się do chorego i zmusza go do modyfikacji, a tym samym do ponownego zbadania swoich nawyków cielesnych, oczekiwań egzystencjalnych, doświadczania ciała, przestrzeni i czasu oraz sposobu bycia na świe$\mathrm{cie}^{62}$. Choroba jest formą gwałtownego zawieszenia naturalnego podejścia i wprowadza procedurę filozoficzną w sposób o wiele bardziej brutalny niż zwyczajna refleksja filozoficzna.

Choroba motywuje chorych, a często i ich otoczenie, do konfrontowania z praktycznymi problemami, co z kolei rodzi teoretyczną refleksję na temat sytuacji cielesnej. Jest to nieproszony rodzaj refleksji, ale takie radzenie sobie z praktycznymi obawami ujawnia normalne warunki, w jakich wcześniej osoba działała w zdrowiu. Zastępuje zdrowie, czyli „życie przeżywane w ciszy narządów", jak napisał francuski chirurg René Leriche ${ }^{63}$. Choroba pozwala na badanie tych warunków, ponieważ ich niezachwiana funkcja zostaje utracona i stają się one przedmiotem bezpośredniej uwagi. Naturalne podejście nie jest odporne na teoretyzowanie lub metarefleksję w okolicznościach, które je zakłócają. Choroba jest właśnie jedną z takich okoliczności.

Merleau-Ponty charakteryzuje epoché jako doświadczenie „zdumienia w obliczu świata" ${ }^{64}$. To zdumienie i konsternacja charakteryzują niektóre doświadczenia związane z chorobą. Na przykład zachęciły Randy'ego Pauscha do napisania The Last Lecture, serii wykładów na temat życia i śmierci, po zdiagnozowaniu u autora raka trzustki. „Wiele osób może oczekiwać, że wykład dotyczy śmierci. Ale musiał on dotyczyć życia", pisze Pausch ${ }^{65}$. Z powodu zmian w somatycznej lub mentalnej architekturze własnego ciała (bądź umysłu) kontakt i doświadczenie świata mogą w chorobie ulec radykalnej modyfikacji. Poczucie komfortu i zażyłości może zostać wyparte przez wyobcowanie i poczucie „nieobecności w domu”66.

62 H. Carel Phenomenology as a resource for patients, s. 96-113.

63 Cyt. za: G. Canguilhem The normal and the pathological, Zone Books, New York 1991, s. 91.

64 M. Merleau-Ponty Phenomenology of perception, 1962, s. XIII.

65 R. Pausch The last lecture, Hodder \& Stoughton, London 2008, s. 9.

66 Zob.: F. Svenaeus Das Unheimliche - towards a phenomenology of illness, "Medicine, Health Care and Philosophy" 2000 no. 3, s. 3-16; tegoż The body uncanny - further steps towards a phenomenology of illness, tamże, s. 125-37. 
Merleau-Ponty pisze: „[Refleksja] rozluźnia celowe wątki, które łączą nas ze światem, by umożliwić ich pojawienie się; sama jest świadoma świata,

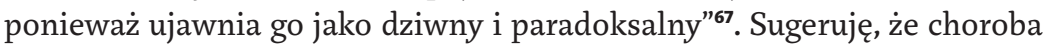
to takie rozluźnienie celowych wątków, które ujawniają świat i cielesność jako niesamowite. Choroba problematyzuje relacje ze światem, zachęcając w ten sposób lub zmuszając do refleksji filozoficznej.

Epoché powstaje także z rozdźwięku między biologicznym a żywym ciałem $^{68}$, który staje się widoczny w chorobie. W zdrowiu te dwa aspekty ciała są zwykle spójne lub harmonijnie reagują na rozmaite doświadczenia ${ }^{69}$.W chorobie ciało biologiczne wysuwa się na pierwszy plan, gdy przestaje współpracować z pragnieniami chorego. Na przykład ciało biologiczne w cukrzycy nie będzie w stanie poradzić sobie z musem czekoladowym, mimo że pragnie tego ciało żywe. Oprócz tego rozłamu ciało biologiczne staje się również źródłem bólu, niepełnosprawności i niepowodzenia. Pod tym względem jest źródłem negatywnych doświadczeń i centrum uwagi medycznej, a te często jeszcze bardziej nas od niego oddalają ${ }^{70}$.

Lawrence Hass uważa chorobę za konflikt między ciałem biologicznym a projektami życiowymi. Podczas gdy „życie osobiste” danego człowieka jest zaangażowane w projekt, ciało biologiczne go blokuje. Na przykład osobistym celem może być zostanie rodzicem. Jeśli jednak ciało biologiczne jest bezpłodne, wynikiem jest zderzenie pragnienia posiadania dziecka $\mathrm{z}$ barierą biologiczną. „Bezosobowe operacje” ciała biologicznego, nad którymi mamy niewielką kontrolę lub nie mamy jej wcale, zakłócają intencjonalny łuk człowieka, znaczący związek między osobą a światem, który mierzy w określony cel $^{71}$. To poczucie, że ciało jest przeszkodą, problemem, czymś, co nie jest już dobrze zrozumiane, może zapoczątkować pewien rodzaj epoché. Status metafizyczny ciała jest kwestionowany, ponieważ nie jest już znany i przewidywalny. Innymi słowy, ciało podlega procesom uprzedmiotowienia

67 M. Merleau-Ponty Phenomenology of perception, 2012, s. xxvii.

68 Husserl dokonał rozróżnienia na „żywe ciało" i „ciało biologiczne”. Ciało biologiczne (Körper) jest obiektem, ciało żywe (Leib) doświadcza wrażeń zmysłowych, jest ich nosicielem. Zob. E. Husserl Idee czystej fenomenologii i fenomenologicznej filozofii, t. 2.

69 Zob. H. Carel Phenomenology of illness, rozdział 2: Phenomenological features of the body.

70 H. Carel Illness.

71 L. Hass Merleau-Ponty's philosophy, Indiana University Press, Bloomington 2008, s. 87. 
w chorobie, a także staje się niesamowitością - dwa procesy, do których teraz się zwracamy ${ }^{2}$.

Uprzedmiotowienie - naturalnym procesem, wtórnym wobec doświadczania żywego ciała, jest doświadczanie ciała jako obiektu wśród przedmiotów. W chorobie proces ten nabiera nowego wymiaru, ponieważ tak współczesna medycyna i wiele nauk leżących u jej podstaw postrzega ciało jako przedmiot fizyczny ${ }^{73}$. To uprzedmiotowienie odbywa się w ramach podwójnego doświadczenia naszego ciała. Ciało jest doświadczane zarówno jako żywe, przedrefleksyjne (pierwszoosobowe doświadczenie z nim i przez nie), jak i zobiektywizowany, obserwowany obiekt przestrzenny (doświadczenie trzecioosobowe ${ }^{74}$. Jest to zarówno przedmiot fizyczny, jak i siedlisko świadomości.

Eksploracja przedmiotów implikuje jednoczesne samozbadanie i samokonstytucję; istnieje więc wzajemna zależność między procesami. „Świat jest nam dany w ramach badań cielesnych, a ciało ujawnia się nam podczas tej eksploracji świata"75. Jesteśmy świadomi obiektów percepcyjnych, ponieważ jesteśmy świadomi naszych ciał i ich wzajemnego oddziaływania. Kiedy badamy przedmioty, zawsze towarzyszy temu pewnego rodzaju samoświadomość cielesna. W wypadku choroby uprzedmiotowienie powoduje powstanie dystansu między sobą a ciałem, które jest teraz przekształcane w obiekt badań i leczenia. Obiektywizacja psuje naturalne, oczywiste podejście do ciała, płynną jedność między ciałem jako przedmiotem a ciałem jako podmiotem.

Merleau-Ponty twierdzi, że ciało jest pierwszym przedmiotem, który postrzegamy jako przedmiot - tematycznym i uczącym interpretacji oraz oceniania go zgodnie ze standardami kulturowymi ${ }^{76}$. Przed tym wydarzeniem

72 Młode, zdrowe ucieleśnienie jest zazwyczaj nieświadome wystąpienia sytuacji, gdy ciało może być doświadczane w ten sposób. Wiara we własne możliwości fizyczne i poznawcze może maskować poczucie, że te zdolności kiedyś się zmienią (chociażby w wyniku naturalnego starzenia się) i że zmiana ta będzie coraz radykalniej wpływać na tożsamość. Może to być postrzegane jako porażka wyobraźni moralnej, współczucia, pokory, a nawet niezrozumienie lub zaprzeczenie biologicznemu kresowi, który wyznacza ludzkie życie. Dziękuję lanowi Jamesowi Kiddowi za zwrócenie mojej uwagi na tę kwestię.

Pragmatycznie rzecz ujmując, jest to coś dobrego. Współczesna medycyna poczyniła ogromne postępy dzięki takiemu spojrzeniu.

Zob.: M. Merleau-Ponty Phenomenology of perception; J.-P. Sartre Being and nothingness. 
nie doświadczam ciała; raczej doświadczam poprzez ciało. Jak pisze Zahavi: „Początkowo moje ciało jest postrzegane jako zunifikowane pole aktywności i afektywności, jako wolicjonalna struktura, potencjał mobilności, jako «robię» $\mathrm{i}$ «potrafię»"77. Choroba utrudnia naturalne poczucie zdolności i aktywności, odsłaniając wolicjonalne struktury wcielenia. Nasza naturalna orientacja to ta, w której ciało służy jako percepcyjne centrum naszego doświadczenia, z naszą uwagą skierowaną raczej od niego niż na nie. Negatywne, niechciane skupienie się na ciele $\mathrm{w}$ chorobie ponownie przesuwa naszą uwagę na ciało, ale tym razem postrzegane jako przedmiot. Wielu z nas doświadczyło prześwietlania lub skanowania ciała i konieczności powiązania naszego subiektywnego poczucia ciała z tym obiektywizującym obrazem.

Dualizm ciała odgrywa złożoną rolę w świadczeniu opieki zdrowotnej. Osoba zatrudniona w opiece zdrowotnej doświadcza ciała pacjentki jako przedmiotu, ale jest również świadoma swojej podmiotowości (przeprasza za zimne dłonie podczas dotykania pacjentki). Pacjentka może czuć się uprzedmiotowiona spojrzeniem lekarza, ale ta obiektywizacja jest możliwa tylko dlatego, że jest ona najpierw podmiotem ${ }^{78}$. Lekarz postrzega pojawienie się doświadczonego obiektu: spuchniętego ramienia. Pacjentka odczuwa zlokalizowane odczucie: obolałe ramię. Można również pokazać jej kliszę z prześwietlonym ramieniem, a zatem oscyluje między dwoma doświadczeniami - bezpośrednim bólem zlokalizowanym w ramieniu a ramieniem jako przedmiotem, na który patrzy i który sobie wyobraża. Może skupić się na odczuwaniu (obserwowaniu spuchniętego ramienia) lub czuciu (samym ramieniu), a każde z nich da odmienne wrażenia tematyczne ${ }^{79}$. Osoby pracujące w opiece zdrowotnej często postrzegają ciało jako tematyczne i zobiektywizowane, koncentrując się na konkretnym organie lub funkcji, aby zrozumieć je jako przedmiot medyczny. Dla rzeczonej pacjentki jednak świadomość jej ciała jako przedmiotu jest drugorzędna w stosunku do jej subiektywnych doświadczeń związanych z leczeniem.

Jak twierdzi Fredrik Svenaeus, współczesna medycyna poszerza obiektywizm ciała przez obrazowanie i konceptualizację narządów, funkcji i procesów

77 D. Zahavi Husserl's phenomenology, s. 101.

78 H. Carel, J. Macnaughton How do you feel? Oscillating perspectives in the clinic, "The Lancet" 2012 vol. 379 (9834), s. 2334-2335.

79 Osoba pracująca w opiece zdrowotnej może również "przełączać się" między wyczuwaniem (doświadczenie pacjentki jako oglądanej na zdjęciu rentgenowskim lub badanej) a czuciem (ramię lub zdjęcie rentgenowskie), ale oscylacja ta nie pociąga za sobą samouprzedmiotowienia. 
molekularnych ${ }^{80}$. Medyczny nacisk na obiektywność ciała przyczynia się do rozłamu między ciałem żywym a ciałem biologicznym. To intensywne doświadczenie obiektywności ciała w chorobie oddziela pacjentkę od jej ciała. Jean-Dominique Bauby, który doznał udaru mózgu, powodującego zespół zamknięcia, pisze:

W odbiciu w gablocie ujrzałem twarz człowieka, którego wyciągnięto $\mathrm{z}$ beczki z dioksyną. Usta wykręcone, nos uszkodzony, włosy w nieładzie, przerażony wzrok. Jedno oko zaszyte, a drugie wytrzeszczone jak oko Kaina. Przez minutę wpatrywałem się w tę zamazaną kukłę i nie potrafiłem zrozumieć, że to ja ${ }^{81}$.

Jak pokazuje ten fragment, choroba może zmusić nas do przyjęcia realnego i niezależnego spojrzenia na nasze własne ciało - jest to zmiana często wymagana od pacjentów podczas omawiania ich choroby z osobami pracującymi w opiece zdrowotnej. Chociaż większość z nas może chwilowo przyjąć obiektywne spojrzenie na własne ciało, nie jesteśmy w stanie go utrzymać; jest to nie do zniesienia. Nie możemy patrzeć na siebie obi ektyw nie w żadnym trwałym sensie i nierealistyczne jest oczekiwanie tego od innych. Osoby pracujące w opiece zdrowotnej muszą zdawać sobie z tego sprawę, ponieważ medycyna uprzywilejowuje perspektywę osób trzecich. Obiektywizm jest postrzegany przez wiele osób pracujących w opiece zdrowotnej jako ideał, ale po poddaniu go analizie filozoficznej można zauważyć, że samo poleganie na obiektywnej postawie jest naiwnym i nieosiągalnym ideałem, który należy zastąpić bardziej dopracowanym rozumieniem intersubiektywności.

Dalsze uprzedmiotowienie zachodzi w klinice. Gdy pacjentka czeka na wyniki badania krwi, jest tak samo nieświadoma poziomu cholesterolu jak obiektywny obserwator. Kiedy pyta lekarza ,jest źle?” - to dlatego, że naprawdę nie jest w stanie uzyskać dostępu do tych informacji poprzez badanie swoich odczuć cielesnych. Ciało pacjentki jest przedmiotem nie tylko dla lekarza, lecz także dla niej samej. Inne doświadczenia zobiektywizowania można zobaczyć w spotkaniach z technologią medyczną. Widzenie swojego guza jako zestawu obrazów tomografii komputerowej lub wyrównywanie

80 F. Svenaeus Organ transplantation and personal identity: How does the loss and change of organs have effects on the self? "J) Journal of Medicine and Philosophy" 2012 vol. 37, no. 2, s. 139-158.

81 J.-D. Bauby The diving bell and the butterfly, transl. by J. Leggatt, Harper Perennial, London 2007; wyd. polskie: Skafander i motyl, przeł. K. Rutkowski, słowo/obraz terytoria, Gdańsk 1997, s. 30. 
kończyn w celu skanowania gęstości kości może sprawić, że obiektywizm ciała znajdzie odwzorowanie w doświadczeniu. Te obiektywizujące doświadczenia mogą prowadzić do poczucia wyobcowania z własnego ciała i do traktowania go jak nienormalnego obiektu, nad którym nie ma się kontroli. Chore ciało staje się pogardzane, przerażające i obce.

Uprzedmiotowienie nie jest jednak kompletne. Istnieje oscylacja między traktowaniem własnego ciała jako przedmiotu medycyny a subiektywnym odczuwaniem lęku, zimna lub wzdryganiem się pod dotykiem lekarza. Przykład Husserla polegający na tym, że dwie dłonie stykają się ze sobą, czyni tę dualność istotną ${ }^{82}$. Kiedy prawa ręka jest aktywna, dotykając drugiej, jest jednocześnie przez nią dotykana. Jeśli świadomie zdecydujemy się odwrócić role i skoncentrować się na lewej ręce jako dotykającej, nadal oscylujemy między oboma wymiarami, aktywnym dotykiem i pasywnym wymiarem bycia dotkniętym.

Jak już wspomniałam w podrozdziale 2.2, ta dualność doświadczenia jest unikatową cechą ludzkiej egzystencji. Aby dotknąć, trzeba być rzeczą między rzeczami, przedmiotem fizycznym. Jako taki przedmiot trzeba być otwartym na możliwość dotknięcia. Jednak w chorobie naturalny ruch między dwoma wymiarami zostaje zakłócony, ponieważ wymiar pasywny staje się widoczny. Na przykład badanie wewnętrzne wywołuje wrażenie dotykania od wewnątrz (np. szyjki macicy lub jelit), rozszerzając domenę bierności. Ciało jako przedmiot ma pierwszeństwo w kontekście klinicznym, a jego obcość jest zaakcentowana dla pacjentki/pacjenta przez niedostępność - inaczej niż za pośrednictwem osoby trzeciej - pewnych faktów medycznych. W chorobie ciało staje się przedmiotem w sposób, którego inaczej by nie osiągnęło.

Niesamowitość - w chorobie ciało staje się przeszkodą i zagrożeniem, nie zaś domem, znanym mi miejscem, w którym mieszkam. Zmiana odczuwania ciała jest zmianą odczuwania bycia w domu w świecie. Ciało przestaje być "zerowym centrum" mojej orientacji na świat ${ }^{83}$ i staje się źródłem negatywnych doświadczeń. Prymitywne poczucie „mogę” zostaje zastąpione świadomym, sztucznym, zapośredniczonym poczuciem „nie mogę”lub „kiedyś byłem

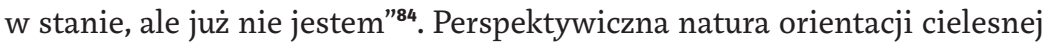
jako podstawy wszelkiego doświadczenia staje się niedrożna.

82 E. Husserl Cartesian meditations.

83 A.D. Smith Husserl and the Cartesian meditations, s. 221.

84 A. Kesselring „The experienced body, when taken-for-grantedness falters: a phenomenological study of living with breast cancer", niepublikowana rozprawa doktorska obroniona na University of California, San Francisco 1990. 
Choroba może zawiesić znane otoczenie i uczucia, które leżą u podstaw normalnych codziennych czynności, powodując zamiast tego doświadczenie "niehomologicznego bycia w świecie"85. Poczucie niesamowitości powstaje najsilniej z zakłócenia tego tła, co dzieje się w wyniku zmienionej cielesności. Nasze koncepcje, zwyczaje, rutyny, oczekiwania i normy mogą zostać zakłócone, a nawet zniszczone przez chorobę. Niesamowitość wynika więc z nowego, negatywnego skupienia na ciele, poczucia, że ciało to staje się obcą siłą destrukcyjną, a nawet z groźby anihilacji. Zmienia to stosunek chorej osoby do jej środowiska, a także jej pojęć.

Choroba powoduje zakłócenie żywego ciała, co burzy relację między ciałem a otoczeniem. Jak zostało omówione we wcześniejszych rozdziałach, pojęcia takie jak „blisko”, „łatwo” zmieniają swoje znaczenie dla jednostki, która może doświadczyć pogłębiającego się poczucia wyobcowania, ponieważ jej nowe użycie pojęć odbiega od normy. Ponadto takie koncepcje nabywają nowe o b i e k t y, np. rutynowe czynności, takie jak noszenie torby z laptopem lub wspinanie się, stają się w chorobie trudne. Wiele pojęć zmienia swoje znaczenie, a także przywiązuje się do nowych obiektów, zmienia więc zakres.

Zmiana nie jest wyłącznie językowa; chory rzeczywiście d o ś w i a d c z a świata fizycznego jako mniej przyjaznego, pełnego przeszkód, trudnego. Odległości rosną, codzienne czynności zajmują więcej czasu, działania muszą zostać porzucone lub przeprojektowane i tak dalej. Toombs opisuje utratę mobilności jako „zakotwiczenie w Tutaj, wywołujące większe poczucie dystansu między sobą a otaczającymi rzeczami" ${ }^{\text {".6 }}$. Choroba modyfikuje nie tylko ciało, lecz także poczucie przestrzeni, co omówiłam w rozdziale $3^{87}$.

Nie tylko doświadczenie przestrzeni i korzystanie z pojęć zmieniają się w chorobie; doświadczenie czasu może się również zmodyfikować oraz przyczynić do poczucia wyobcowania i niewiedzy wywołanej zmianami cielesnymi, strachem, bólem i ograniczeniami. Utrzymujący się ból lub złe rokowania mogą całkowicie zmienić doświadczanie czasu ${ }^{88}$. Zajęcia mogą wymagać więcej czasu, a tym samym się rozciągać, lub mogą stać się niemożliwe do wykonania, co może spowodować, że chora osoba poczuje się „bezużyteczna”

\footnotetext{
85 F. Svenaeus, Das Unheimliche, s. 9; tegoż Organ transplantation and personal identity, s. 139-158. S.K. Toombs The temporality of illness: four levels of experience, "Theoretical Medicine" 1990 vol. 11, s. 11.

87 H. Carel Phenomenology of illness, rozdział 3: The body in illness.

88 S.K. Toombs The temporality of illness.
} 
lub bardziej niepełnosprawna niż w rzeczywistości ${ }^{89}$. Niepewność i lęk przed przyszłym stanem zdrowia i zdolnościami mogą skupić się na teraźniejszości ${ }^{90}$. A wspomnienia zdrowej przeszłości stają się przedmiotem żalu, tęsknoty lub poczucia nieciągłości ${ }^{91}$.

Doświadczenie czasu może również zmienić się w odpowiedzi na niepewne rokowania. Priorytety mogą ulegać modyfikacji i jest to okazja do pytania, jak ktoś żył i jak chciałby żyćc2. Zmiany te są fundamentalne i mogą prowadzić do przemiany tożsamości ${ }^{93}$, a także wywoływać pytania filozoficzne. Jak plastyczne jest doświadczenie czasu i przestrzeni? Co decyduje o „normalnym” doświadczeniu? Czy może istnieć ciągłość tożsamości i osobowości, biorąc pod uwagę radykalną zmianę własnych doświadczeń? Sposób, w jaki tego typu pytania powstają w wyniku zmian cielesnych w chorobie, pokazuje, że może ona motywować lub służyć za bramę do aktywności filozoficznej.Teraz przechodzimy do zbadania filozoficznego znaczenia takiego motywowania.

\subsection{Choroba jako zaproszenie do filozofowania}

Do tej pory wyjaśniłam, w jaki sposób choroba może być filozoficznie pouczająca, zaburzając codzienne, oczywiste założenia o cielesnej egzystencji, a tym samym dokonując pewnego rodzaju epoche $e^{94}$. W tej części przyglądam się bliżej temu procesowi i sugeruję, że choroba daje swoistą motywację do filozofowania.

Choroba jest niepożądana; prawie nigdy nie jest mile widziana ani łatwo przyjmowana. Jest to także wydarzenie radykalne: powoduje przemyślenie wartości i znaczeń, przez wzięcie pod uwagę zmienionych warunków życia.

89 S.K. Toombs Illness and the paradigm oflived body " Theoretical Medicine" 1988 vol. 9, s. 201-226.

90 H. Carel Illness, rozdział 5: Phenomenology of breathlessness.

91 M. Bury Chronic illness as biographical disruption, "Sociology of Health and Illness" 1982 vol. 4, no. 2 , s. $167-182$.

92 E. Lindsey Health within illness: experiences of chronically ill/ disabled people , Journal of Advanced Nursing" 1996 vol. 24, s. 465-472; O. Lindqvist, A. Widmark, B. Rasmussen Reclaiming welIness - living with bodily problems as narrated by men with advanced prostate cancer, "Cancer Nursing" 2006 vol. 29, no. 4, s. 327-337.

S.J. Williams Medicine and the body.

94 Proces ten może wpływać na członków rodziny lub opiekunów, którzy zostają odsunięci od wspólnych praktyk i rozumienia ograniczeń związanych z chorobą, mimo że nie doświadczają ich osobiście. 
Poważna choroba jest dramatycznym wydarzeniem życiowym, które wpływa na wszystkie jego aspekty.Z powodu tych cech choroba może m o ty w o w a ć do refleksji filozoficznej. Jednak nie tylko choroba może zmotywować do refleksji osobę, która zachoruje, choć jak już pokazałam w niniejszej książce, jest to prawda ${ }^{95}$. Co ważniejsze, cechy, które motywują do refleksji u chorych, sprawiają, że choroba staje się istotna dla praktyki filozoficznej.

Choroba zachęca lub inspiruje do refleksji filozoficznej. Ale może również tę refleksję brutalnie na chorych wymusić. Rozważmy, w jaki sposób złe rokowanie może zmusić chorego do stawienia czoła śmierci. Zmusza go do rozważenia śmierci nie w sposób abstrakcyjny - domena zdrowych i młodych - ale w najbardziej ingerujący i przerażający. Choroba nie pozwala na nieautentyczne podejście do śmierci jako abstrakcyjnego, odległego wydarzenia. Zmusza chorego do stawienia czoła własnej śmierci w najbardziej konkretny sposób. Jest wymagającym instruktorem filozoficznym, zmuszającym chorego do stawienia czoła śmierci w jak najkrótszym czasie. Można postrzegać to jako pełniejszą, bardziej egzystencjalną formę filozofowania. Rzeczywiście dla Heideggera autentyczne stawienie czoła śmierci wymaga właśnie tego rodzaju pierwszoosobowego zaangażowania w śmiertelność.

Choroba różni się także od innych motywacji do filozofowania. Podczas gdy zwykle wybiera się procedurę filozoficzną, na przykład kwestionowanie lub krytykę argumentu, choroba jest gwałtowna, niechciana, destrukcyjna i niekontrolowana. Zazwyczaj praktykę filozoficzną traktujemy jako kwestię wyboru, podczas gdy choroba jest rzadko wybierana. Myślimy o refleksji jako przyjemnym doświadczeniu wyzwania intelektualnego, natomiast przemyślenia wywołane przez chorobę są pochłaniające, ekstremalne i przerażające.

Choroba wpływa na różne aspekty refleksji filozoficznej: może wymagać bardziej radykalnych i osobistych metod, takich jak egzystencjalizm lub nihilizm. Wpływa na filozoficzne obawy chorego - kwestie takie jak śmierć, dobre życie, związek przyczynowy i czas mogą być kluczowe i napierające na chorego w sposób, w jaki inaczej by ich nie doświadczał. Ponieważ zachodzi tutaj przymuszenie do zaangażowania się w fizyczny lub psychiczny upadek i śmierć, wywołuje ono refleksję nad skończonością, niepełnosprawnością, cierpieniem, niesprawiedliwością. Podobnie pilność i istotność poszczególnych tematów filozoficznych może ulec zmianie w zależności od choroby ${ }^{96}$.

95 Niekoniecznie jest to prawda, ponieważ choroba może spotkać się z wyparciem, zaprzeczeniem lub innymi mechanizmami obronnymi, które blokują refleksyjność. 
Także sama działalność filozofowania może się zmienić i stać się bardziej nagląca i osobista.

Choroba może też zmodyfikować pojmowanie filozofii chorej osoby (jeśli ją uprawia) jako istotną praktykę mającą na celu dobre życie, a nie na przykład badanie teoretyczne. Dawny pogląd na filozofię można znaleźć w starożytnych szkołach filozoficznych, takich jak epikurejczycy i stoicy - i być może wynika to częściowo z ograniczonej w tym okresie zdolności leczenia chorób i kontrolowania bólu. Przy tak skromnych zdolnościach pojawia się potrzeba zmiany postawy wobec choroby; jest to całkowicie odmienne od podejścia „wylecz za wszelką cenę", które propaguje się w wielu stanowiskach współczesnej medycyny ${ }^{97}$.

Choroba potrafi również wywoływać poczucie, że dociekania filozoficzne powinny być zintegrowane z życiem jako całością. Przykładem tego podejścia jest Alasdair MacIntyre, który podkreśla nasz wrażliwy, zależny, dolegliwy stan jako warunek wstępny stylu moralnego filozofowania uważnego na kondycję ludzką ${ }^{98}$. Choroba jest szczególnie ważna pod względem etycznym z powodów wskazanych przez MacIntyre'a: aby zrozumieć cnotę, dobroć i współczucie, musimy spojrzeć na te doświadczenia życiowe, które naprawdę wzywają do gry, a nawet je przetestować i być chorym, dbać o chorych lub empatycznie współpracować z chorymi ludźmi. Jednak wiele prac w dziedzinie etyki nadal ignoruje to, że ludzie chorują i że dobre reagowanie wymaga pewnych cnót, takich jak współczucie, empatia, cierpliwość i odwaga.

I wreszcie, jak sugeruje Ian James Kidd (komunikacja osobista), nawet metafizyka może szukać choroby w celu uzyskania instrukcji99. Choroba może nas nauczyć pewnych prawd o naturze rzeczywistości (lub nawet odegrać je w naszych własnych ciałach). Na przykład buddyści mogą interpretować doświadczania choroby somatycznej jako pouczające nie tylko w kwestii niektórych prawd moralnych, ale jako prawdy metafizyczne - choćby jako uwarunkowana natura wszystkich zjawisk i poddanie wszystkich rzeczy nietrwałości i strumieniowi (anicca).

Jednak choroba nie zawsze lub niekoniecznie wypełnia zadanie zachęcania do filozofowania. Jest dezorientująca i przytłaczająca. Może, podobnie jak inne ekstremalne trudności, niszczyć refleksyjność, zamiast ją wywoływać.

97 A. Gawande Being mortal: illness, medicine and what matters in the end, Profile Books, New York 2015 . 
Choroba sama w sobie nie jest refleksją filozoficzną, ale może być - i często jest - d rogą d o refleksji. To kompulsywne zaproszenie do filozofowania. Jest ono kompulsywne, ponieważ go nie wybieramy, ale jest zaproszeniem, ponieważ nie zawsze je podejmujemy. To kompulsywne zaproszenie zostało opisane w wielu patografiach ${ }^{100}$ :

Doświadczenie choroby i jej ogólny wpływ na każdy aspekt życia zaskoczyło mnie i pchnęło do myślenia o tych kwestiach. Przekonałam się, że muszę odkryć na nowo swoje życie [...]. Nauczyłam się rozważać swoje aspiracje i plany. Porzuciłam poczucie kontroli, które wcześniej miałam [...]. Moje doświadczenia skłoniły mnie do refleksji nad zdrowiem i chorobą. ${ }^{101}$

\subsection{Zakończenie}

Prawdziwa filozofia, jak mówi Merleau-Ponty, „pociąga za sobą naukę patrzenia na świat na nowo"102. Choroba zmusza nas do uczenia się nie tylko ponownego badania świata, lecz także radzenia sobie z nim, negocjowania nowych ograniczeń i kontynuowania życia najlepiej, jak potrafimy, w ramach zastanych ograniczeń. Rezultatem takiego radzenia sobie z praktycznymi ograniczeniami może być egzystencjalne i filozoficzne olśnienie (wyjaśnienie). Być może choroba jest rodzajem filozoficznej metody, która oświetla normalność poprzez jej patologiczny odpowiednik. Merleau-Ponty wzywa nas jednak do ostrożnego dochodzenia tego roszczenia:

Niemożliwe jest wydedukowanie normalności z patologicznych niedociągnięć funkcji zastępczych przez zwykłą zmianę znaku. Musimy traktować substytucje jako substytucje, jako aluzje do jakiejś fundamentalnej funkcji, którą starają się uczynić dobrą, oraz bezpośredniego obrazu, którego nie dostarczają. ${ }^{103}$

Merleau-Ponty zdaje sobie sprawę, że patologia to nie tylko „zmiana znaku". Przeciwnie, przypadki patologiczne wskazują na jakąś funkcję, która

\footnotetext{
100 A. Frank At the will of the body; R. Pausch The last lecture.

101 H. Carel Illness, s. 9.

102 M. Merleau-Ponty Phenomenology of perception, 2012, s. xxxv.

103 Tamże, s. 110.
} 
"dąży do czynienia dobra" i w tym dążeniu tworzy kompletną formę życia. Ta kompletność wymaga dalszych badań filozoficznych, aby odkryć, w jaki sposób to, co może wydawać się patologiczne i niedostateczne, potrafi powodować takie zjawiska, jak adaptacja ${ }^{104} \mathrm{i}$ edyfikacja ${ }^{105}$. Georges Canguilhem zdefiniował chorobę jako „nowy sposób życia organizmu”, stworzenie nowych norm rządzących relacją chorego organizmu z jego środowiskiem ${ }^{106}$. Bogactwo doświadczenia choroby, rozumienia zdrowia i choroby jako działalności wyraźnie n or maty w nej świadczy o tym, że choroba wymaga dalszych poszukiwań filozoficznych i na to zasługuje.

Wśród myślicieli starożytnej Grecji, Indii i Chin filozofia pełniła funkcję praktyki życiowej ukierunkowanej na dobre życie, co Pierre Hadot nazwał "sposobem życia"107. Filozofia była zdyscyplinowanym systemem transformacji etycznej, który zwykle następował po uznaniu, że ludzkie życie charakteryzuje zamieszanie, ignorancja, rozpacz i cierpienie. Uznanie to znajduje odzwierciedlenie w wielkich ambicjach tych starożytnych tradycji filozoficznych, aby uwolnić ludzi od cierpienia oraz budować i ulepszać ludzkie życie. Rozpoznano w nich wiele form cierpienia, wśród nich najważniejsza była choroba fizyczna - „choroba jest cierpieniem”, mówi Pierwsza Szlachetna Prawda nauczana przez Buddę, podobnie jak „ból, żal i rozpacz” - a wielu starożytnych myślicieli stosowało metafory medyczne do opisania swojej praktyki ${ }^{108}$.

W dużej mierze zapomnieliśmy o fronetycznych początkach filozofii i o tym, że ta praktyka w formie dążenia do dobrego życia przychodzi nam naturalnie. Spontaniczny impuls do filozofowania należy aktywnie zniechęcać, o czym wie każdy, kto uczył dzieci filozofii. Impuls ten budzi się ponownie u niektórych osób w czasach kryzysów egzystencjalnych, na przykład spowodowanych chorobą, traumą lub żalem. To pozytywne, acz nieoczekiwane

104 H. Carel Can I be ill and happy?, „Philosophia” 2007 vol. 35, no. 2, s. 95-110.

105 I.J. Kidd Can illness be edifying?

106 G. Canguilhem The normal and the pathological, s. 84.

107 P. Hadot Filozofia jako ćwiczenie duchowe, przeł. P. Domański, Fundacja Aletheia, Warszawa 2003.

108 Mowa tu o buddyjskich Czterech Szlachetnych Prawdach (Szlachetna Prawda o Cierpieniu, Szlachetna Prawda o Przyczynie Cierpienia, Szlachetna Prawda o Wygaśnięciu Cierpienia, Szlachetna Prawda o Ścieżce Wiodącej do Zniszczenia Cierpienia), zob. B. Bhikkhu The collected discourses of the Buddha: a new translation of the Samyutta Nikaya, Wisdom Publications, Somerville 2000. 
przebudzenie impulsu filozoficznego musi zostać wyrażone. Może on, w połączeniu z wglądem, że choroba nie wyklucza dobrostanu, pocieszać nas świadomością - i że choroba może zakłócić, ale nie zniszczy dążenia do dobrego życia. Dobre życie zawiera oświecenie i zaciemnienie, nagrodę i wyzwanie. Ta mieszanka jest niezbędna dla ludzkiego życia, jakie znamy. Napięcie i dialektyka między dwiema stronami życia podtrzymują i pielęgnują refleksję filozoficzną oraz promują postawę egzystencjalną.

Susan Sontag opisuje chorobę jako „nocną stronę życia”, inne królestwo, wymagające paszportu, aby wejść do niego z królestwa studni. Opisuje fantazję społeczną, w której zaprzecza się śmierci i śmiertelności, co prowadzi do poczucia, że świat chorych jest inny i oddzielony od świata, jeśli jest zdro$w^{109}$.To oczywiście złudzenie. Wszyscy uczestniczymy w królestwie chorych, przynajmniej z zasady. Wszyscy zaczynamy całkowicie polegać na innych i na tym najczęściej kończymy.

Przemijanie naznacza ludzkie życie. Oba królestwa są ze sobą połączone, a przejście z jednego do drugiego jest jedynym pewnym faktem życia ludzkiego takiego, jakie ono obecnie jest. Świat chorych różni się pod wieloma względami od świata zdrowych. Jego przestrzeń i czas są różne; jego ograniczenia zaciemniają możliwości; wymaga od chorych życia w napiętej bliskości cierpienia i śmierci. Ale świat chorych zależy od norm zdrowych; a świat zdrowych zależy od świata chorych w kwestii aberracji tych norm. Oba królestwa wzajemnie się ze sobą przenikają. Żyjemy w obu, choć robimy wiele, aby temu zaprzeczyć.

\section{*⿻*}

Jest jesień, a park przy naszym domu jest pokryty suchymi liśśmi. Liście dają ciepły blask żółci, pomarańczu i brązu, zachęcają nas do tarzania się w nich, podrzucania ich. Mój pies biegnie przez duże stosy liści, podekscytowany jesiennymi zapachami. Widzę matkę idącą z dwoma synami. Pochyla się i nabiera garść liści, którą dla zabawy wciska pod ich płaszcze. Śmieją się i gonią ją wokół drzewa, szukając odwetu. Biegnie, pochyla się szybko, by zebrać więcej liści, rzuca je w powietrze, ścigają się, gonią i są ścigani. Śmieją się i nawołują do siebie. Myślę, że do tego potrzeba tyle powietrza. Przechodzę za nimi powoli, obserwując ich zabawę, fizyczną radość. Ta radość mi się udziela, ale

109 S. Sontag Illness as metaphor, Farrar, Straus and Giroux, New York 1978; wyd. polskie: Choroba jako metafora, przeł. J. Anders, Wydawnictwo Karakter, Kraków 2016. 
już nie mogę dołączyć. Uśmiecham się, gdy wspinam się na wzgórze, powoli, powoli, zawsze uważając na tlen, tak swobodnie dostępny w powietrzu wokół nas i tak niewidoczny dla tych, którzy mogą go mieć tyle, ile pragną.

Przełożyła Łucja Lange

\section{Abstract}

\section{Havi Carel}

UNIVERSITY OF BRISTOL

The Philosophical Role of Illness

This article examines the philosophical role of illness. It briefly surveys the philosophical role accorded to illness in the history of philosophy and explains why illness merits such a role. It suggests that illness modifies, and thus sheds light on, normal experience, revealing its ordinary and therefore overlooked structure. Illness also provides an opportunity for reflection by performing a kind of suspension (epoché) of previously held beliefs, including tacit beliefs. The article argues that these characteristics warrant a philosophical role for illness. While the performance of most philosophical procedures is volitional and theoretical, however, illness is uninvited and threatening, throwing the ill person into anxiety and uncertainty. As such it can be viewed as a radical philosophical motivation that can profoundly alter our outlook. The article suggests that illness can change the ways in which we philosophise: it may shape philosophical methods and concerns and change one's sense of salience and conception of philosophy.

\section{Keywords}

phenomenology, illness, philosophical method, Merleau-Ponty, epoche, Husserl 